\title{
Association of HIV infection with distribution and viral load of HPV types in Kenya: a survey with 820 female sex workers
}

Stanley MF Luchters ${ }^{1,2}$, Davy Vanden Broeck ${ }^{1,2}$, Matthew F Chersich ${ }^{2,3^{*}}$, Annalene Nel $^{4}$, Wim Delva ${ }^{2,8}$, Kishor Mandaliya ${ }^{5}$, Christophe E Depuydt ${ }^{6,7}$, Patricia Claeys ${ }^{2}$, John-Paul Bogers ${ }^{6,7}$, Marleen Temmerman ${ }^{2}$

\begin{abstract}
Background: Human papillomavirus (HPV) and HIV are each responsible for a considerable burden of disease. Interactions between these infections pose substantial public health challenges, especially where HIV prevalence is high and HPV vaccine coverage low.

Methods: Between July 2005 and January 2006, a cross-sectional community-based survey in Mombasa, Kenya, enrolled female sex workers using snowball sampling. After interview and a gynaecological examination, blood and cervical cytology samples were taken. Quantitative real-time PCR detected HPV types and viral load measures. Prevalence of high-risk HPV was compared between HIV-infected and -uninfected women, and in women with abnormal cervical cytology, measured using conventional Pap smears.

Results: Median age of the 820 participants was 28 years (inter-quartile range [IQR] $=24-36$ years). One third of women were HIV infected (283/803; 35.2\%) and these women were y more likely to have abnormal cervical cytology than HIV-negative women $(27 \%, 73 / 269$, versus $8 \%, 42 / 503 ; P<0.001)$. Of HIV-infected women, $73.3 \%$ had high-risk HPV (200/273) and 35.5\% had HPV 16 and/or 18 (97/273). Corresponding figures for HIV-negative women were $45.5 \%$ (229/503) and 15.7\% (79/503). After adjusting for age, number of children and condom use, high-risk HPV was 3.6 fold more common in HIV-infected women $(95 \% \mathrm{Cl}=2.6-5.1)$. Prevalence of all 15 of the high-risk HPV types measured was higher among HIV-infected women, between 1.4 and 5.5 fold. Median total HPV viral load was $881 \mathrm{copies} / \mathrm{cell}$ in HIV-infected women (IQR $=33-12,110 \mathrm{copies} / \mathrm{cell})$ and 48 copies/cell in HIV-uninfected women $($ IQR $=6-756$ copies/cell; $P<0.001)$. HPV 16 and/or HPV 18 were identified in $42.7 \%$ of LSIL (32/75) and $42.3 \%$ of HSIL $(11 / 26)$ lesions $(P=0.98)$. High-risk HPV types other than 16 and 18 were common in LSIL $(74.7 \% ; 56 / 75)$ and HSIL (84.6\%; 22/26); even higher among HIV-infected women.
\end{abstract}

Conclusions: HIV-infected sex workers had almost four-fold higher prevalence of high-risk HPV, raised viral load and more precancerous lesions. HPV 16 and HPV 18, preventable with current vaccines, were associated with cervical disease, though other high-risk types were commoner. HIV-infected sex workers likely contribute disproportionately to HPV transmission dynamics in the general population. Current efforts to prevent HIV and HPV are inadequate. New interventions are required and improved implementation of existing strategies.

\footnotetext{
* Correspondence: mchersich@rhru.co.za

${ }^{2}$ International Centre for Reproductive Health (ICRH), Ghent University, Belgium
} 


\section{Background}

Human papillomavirus (HPV) is the most common sexually transmitted infection (STI) worldwide. It is the pre-eminent etiologic agent of cervical cancer, the second most common cancer among women [1]. Over 100 HPV types have been identified, about 20 of which are termed high-risk types, because of their propensity to disrupt control of normal cell-cycles and thereby foment the development of cervical malignancy [2]. In addition to cervical neoplasia, HPV is also causally associated with anogenital, oropharyngeal and some skin cancers $[3,4]$. HIV, another STI with extensive public health impact [5], shares many common behavioural risk factors with HPV and the infections interact in important ways. Female sex workers (FSW) have a particularly high risk for both HIV and HPV infection, and the interactions between these infections are especially pronounced in this population group [6-8].

Women with HIV infection commonly have a broader range of HPV genotypes, often with multiple concurrent HPV infections [9]. HIV disease influences the natural history of HPV by increasing the likelihood of persistent infection and virulence, and hastening the time-course of HPV disease [10]. Thus, compared with HIV-negative women, HIV-positive women are more likely to progress to cervical cancer, have a worse prognosis and a higher risk of recurrence [11-13]. It is also important to note that the interplay between HIV and HPV infection, and the consequences thereof are influenced by other factors such as age, sexual practices and socio-economic characteristics of women [14-16].

Besides the effects of HIV on the natural history of HPV infection, it is possible that HIV affects the transmissibility of HPV, and even possibly vice versa [17-19]. Causality, and the potential bidirectional nature thereof, cannot yet be definitively determined from available, mostly cross-sectional evidence. It remains plausible, however, that enhanced friability and the recruitment of CD4 and dendritic cells with HPV infection increases susceptibility to HIV acquisition in a manner similar to other genital tract infections such as Neisseria gonorrhoea.

The HPV vaccine, including high-risk HPV types 16 and 18, is effective in reducing HPV infection and HPVrelated disease in women, and potentially in men [20]. These vaccines are increasingly becoming available in resource-constrained settings [21], which carry the overwhelming burden of HPV disease. Additional information about the prevalence of high-risk HPV types and their relative contribution to cervical disease in this setting would assist in planning for vaccine implementation and future development. This study assesses the prevalence of high-risk HPV types and HIV among FSW in
Mombasa, Kenya, and the associations between these infections and with other demographic and behavioural variables. Additionally, the complex inter-relationships between type-specific HPV viral load, HIV infection and cervical cytology are evaluated.

\section{Methods}

\section{Setting and population}

Mombasa, in Kenya's Coast province, is a major economic centre in the region, with important tourism, port, rail and industrial enterprises, as well as a large FSW population. Sex workers in Mombasa are working either full- or part-time from bars, hotels, streets or from their homes [22,23]. About a third are involved in other small businesses, including selling foodstuffs, vegetables and, in some areas, local brew on the roadside [23]. Commonly the clients of sex workers are employed at local factories or are matatu (minibus taxi) touts or drivers.

\section{Study Design}

Between July 2005 and January 2006, 820 FSW from Chaani and Kisauni divisions of Mombasa were enrolled in a community-based, cross-sectional survey. FSW were recruited using snowball sampling, a method appropriate for locating difficult-to-reach populations, particularly those with stigmatized behaviours or professions [24]. Full details of study methodology are provided elsewhere [23]. In brief, initial respondents were identified from bars, guest houses and the street, with subsequent participants recruited using snowball sampling. To limit the potential for friendship bias, we restricted the maximum number of women recruited through one participant to 10. Eligible participants were self-reported FSW, older than 16 years and working within Kisauni or Chaani. For this study, sex workers were defined as any woman who reported having received money or gifts in exchange for sex in the past year. The Kenyatta National Hospital Ethics and Review Committee reviewed and provided approval for the study procedures.

\section{Study procedures}

In the two study areas, an existing drop-in centre for FSW and a municipality run health centre were modified to include clinical examination areas and related research facilities. Here staff obtained written informed consent, collected demographic and behavioural data using structured questionnaires, and offered HIV counselling and same-day testing. Blood plasma samples were taken and a gynaecological examination was done with speculum insertion, and collection of endocervical and high vaginal swabs.

Cervical samples were collected using a cervix brush (Cervex-brush ${ }^{\circ}$, Rovers ${ }^{\circ}$, Oss, The Netherlands) and 
cervical cytology was assessed with conventional Papanicolaou (Pap) smears. Slides were read by a cytologist with masters level training, supervised by a pathologist. An external cytopathologist provided quality control. The Bethesda Reporting System was used for cytologic classification [25]. The cervix brush tips were preserved in a liquid-based cytology collection medium (SurePath ${ }^{\circ}$, Tripath Imaging Inc., Burlington, North Carolina, USA) and stored at $4^{\circ} \mathrm{C}$ until further processing.

HPV testing was done as described by Depuydt et al [26] in an accredited laboratory (ISO certification: ISO15189). Briefly, HPV DNA was extracted from exfoliated cervical cells using the standard proteinase $\mathrm{K}$ based digestion protocol, following the manufacturer's instructions. Cells were incubated with proteinase $\mathrm{K}$ solution $(100 \mu \mathrm{g} / \mathrm{ml})$ for 3 hours at $55^{\circ} \mathrm{C}$. DNA was then further purified by spin column chromatography. HPV types were determined using a series of real-time PCR reactions with specific primers and TaqMan (Invitrogen, La Jolla, USA) probes for high-risk HPV types 16, $18,31,33,35,39,45,51,52,53,56,58,59,66$ and 68 [2]. Low-risk HPV types 6 and 67 were also detected.

A parallel testing algorithm was used for HIV diagnosis using rapid immunoassays: Uni-Gold ${ }^{\text {tw }}$ Recombigen $^{\circ}$ HIV (Trinity Biotech plc, Bray, Ireland) and Determine HIV-1/2 (Abbott Japan co Ltd, Minato-Ku, Tokyo, Japan). In the case of indeterminate results, an enzymelinked immunosorbent assay was used to confirm HIV status.

Where indicated, FSW received STI treatment free of charge. Women with a positive HIV test were referred to a nearby HIV clinic where medical care and antiretroviral treatment are provided, with no user fees. Women with abnormal cervical cytology were referred for further management and follow-up at the provincial teaching and referral hospital (Coast Provincial General Hospital, Mombasa) or a local municipal clinic supported by the International Centre for Reproductive Health.

\section{Data management and analysis}

Data were double entered by separate data clerks. Following data checking and cleaning, analysis was done using Intercooled Stata, version 10.0 (Stata Corporation, College Station, TX, USA). The presence of any detectable viral load for specific HPV types was considered diagnostic for infection with that specific type. Chisquare tests were used to detect differences in HPV prevalence in women with and without HIV infection. For each HPV type, the Mann-Whitney $U$ test was used to compare the HPV viral load of HIV infected and uninfected women who had $\geq 1 \mathrm{HPV}$ copy/cell. Total HPV viral load was also calculated for each woman (the sum of the viral load of each high-risk HPV infection). To account for differences in age distribution between HIV infected and uninfected women, age-adjusted risk ratios are presented comparing the risk of HPV infection in these two groups. A multivariable logistic regression model was constructed, in which the presence of any high-risk HPV infection was the dependent variable. Fitting of the regression model was done using stepwise backward elimination, with variables retained if their removal markedly altered model parameters [27]. Variables associated with high-risk HPV in univariate analysis $(P<0.1)$ were included in the initial model. Associations between high-risk HPV infection and abnormal cervical cytology were also assessed.

\section{Results}

Socio-demographic and sexual behaviour characteristics The median age of the 820 enrolled FSW was 28 years $(\mathrm{IQR}=24-36$ years; table 1$)$. The vast majority were currently single, either never been married $(346 / 818$; $42.3 \%)$ or separated $(33.0 \%, 270 / 818)$, divorced $(13.0 \%$, $106 / 818)$ or widowed $(8.9 \%, 73 / 818)$. Women had a median of two children (IQR $=1-3$ children).

Women obtained clients mainly at bars or nightclubs $(70.7 \%, 580 / 820)$, though about a fifth worked mainly from home $(163 / 820)$. The median income from sex work per week was 14.3 US\$ (IQR $=8.1-27.0$ US\$; exchange rate of US $\$ 1=74$ Kenya shillings), obtained from a mean of 2.3 sex partners per week (standard deviation $(\mathrm{sd})=0.7)$. About two thirds of women reported consistently using a condom with clients $(63.2 \%, 518 / 820)$, while consistent condom use with boyfriends was reported by only 92 of 437 women who currently had a boyfriend (21.1\%).

\section{Prevalence of HIV}

A third of participants were HIV infected (283/803; $35.2 \%$ ) HIV status was unknown in 17 women. Compared to HIV-negative women, infected women were a median 3 years older. With each increase in decade of age, the odds of HIV infection increased 1.6 fold $(95 \% \mathrm{CI}$ $=1.4-2.0 ; P<0.001)$. Prevalence of HIV was lower in Muslim $(25.4 \%, 58 / 228)$ than in other women $(39.1 \%$, $225 / 575 ; P<0.001)$ and women with a shorter duration of sex work (median 4 years [IQR $=2$-7] for HIV-negative women versus median 5 years [IQR $=3-9]$ for positive women; $P=0.002$ ). HIV prevalence was also higher in widowed women $(62.9 \%, 44 / 70$ compared with $32.6 \%$, 238/731 in other women; $P<0.001)$ and in those with a recent genital sore $(42.3 \%, 66 / 156$ versus $33.6 \%$, 217/646 in women without history of genital sores; $P=0.04$ ).

\section{Prevalence of HPV infection}

Of the 820 participants, study samples of adequate quality were obtained from 786 women for Pap smear 
Table 1 Distribution of demographics and sexual behaviour by HIV status and presence of high-risk HPV infection among female sex workers in Mombasa Kenya

\begin{tabular}{|c|c|c|c|c|c|c|c|}
\hline \multirow[b]{2}{*}{ Variable } & \multirow[b]{2}{*}{ All women } & \multicolumn{2}{|c|}{ HIV-negative women } & \multirow[b]{2}{*}{$P$} & \multicolumn{2}{|c|}{ HIV-positive women } & \multirow[b]{2}{*}{$P$} \\
\hline & & $\begin{array}{r}\text { No high-risk } \\
\text { HPV }\end{array}$ & $\begin{array}{r}\text { High-risk } \\
\text { HPV }\end{array}$ & & $\begin{array}{r}\text { No high-risk } \\
\text { HPV }\end{array}$ & $\begin{array}{r}\text { High-risk } \\
\text { HPV }\end{array}$ & \\
\hline \multicolumn{8}{|l|}{ Age n/N (\%) } \\
\hline $17-24$ & 232/817 (28.4) & $81 / 272(29.8)$ & $88 / 229(38.4)$ & & 13/73 (17.8) & $38 / 199$ (19.1) & \\
\hline $25-29$ & 216/817 (26.4) & $72 / 272(26.5)$ & $64 / 229(28.0)$ & & 14/73 (19.2) & $54 / 199(27.1)$ & \\
\hline $30-39$ & 246/817 (30.1) & $84 / 272(30.9)$ & $55 / 229(24.0)$ & & 28/73 (38.4) & 68/199 (34.2) & \\
\hline$\geq 40$ & 123/817 (15.1) & $35 / 272(12.9)$ & $22 / 229(9.6)$ & $0.02+$ & 18/73 (24.7) & 39/199 (19.6) & $0.26+$ \\
\hline median years $(\mathrm{IQR})^{*}$ & $28(24-36)$ & $28(23-35)$ & $27(22-32)$ & 0.02 & $32(27-39)$ & $30(26-38)$ & 0.27 \\
\hline \multicolumn{8}{|l|}{ Religion n/N (\%) } \\
\hline Catholic & 255/820 (31.1) & $76 / 274(27.7)$ & $67 / 229(29.3)$ & & 26/73 (35.6) & $77 / 200(38.5)$ & \\
\hline Muslim & 236/820 (28.8) & $89 / 274(32.5)$ & $78 / 229(34.1)$ & & 12/73 (16.4) & $42 / 200(21.0)$ & \\
\hline Protestant & $313 / 820(38.2)$ & $101 / 274(36.9)$ & $78 / 229(34.1)$ & & $34 / 73(46.6)$ & $80 / 200(40.0)$ & \\
\hline Other & 16/820 (2.0) & 8/274 (2.9) & 6/229 (2.6) & 0.92 & 1/73 (1.4) & $1 / 200(0.5)$ & 0.62 \\
\hline \multicolumn{8}{|l|}{ Education level n/N (\%) } \\
\hline Never attended school & $82 / 820(10.0)$ & $33 / 274(12.0)$ & $17 / 229(7.4)$ & & 6/73 (8.2) & $22 / 200(11.0)$ & \\
\hline Primary school & $513 / 820(62.6)$ & 164/274 (59.9) & $148 / 229(64.6)$ & & 45/73 (61.6) & $128 / 200(64.0)$ & \\
\hline Secondary school & 202/817 (24.8) & $67 / 274(24.5)$ & $57 / 229(24.9)$ & & 20/73 (27.4) & 49/200 (24.5) & \\
\hline Tertiary education & 22/817 (2.7) & 10/274 (3.7) & $7 / 229(3.1)$ & 0.35 & 2/73 (2.7) & $1 / 200(0.5)$ & 0.38 \\
\hline \multicolumn{8}{|l|}{ Marital status n/N (\%) } \\
\hline Never married & $346 / 818(42.3)$ & $113 / 274(41.2)$ & 109/228 (47.8) & & 25/73 (34.3) & 78/199 (39.2) & \\
\hline Married or cohabitating & 23/818 (2.8) & 15/274 (5.1) & $4 / 228(1.8)$ & & $0 / 0(0)$ & 5/199 (2.5) & \\
\hline Separated, divorced or widowed & $449 / 818(54.9)$ & $147 / 274(53.7)$ & $115 / 228(50.4)$ & 0.07 & 48/73 (65.8) & 116/199 (58.3) & 0.26 \\
\hline \multicolumn{8}{|l|}{ Number of live children n/N (\%) } \\
\hline 0 & 114/819 (13.9) & $39 / 274(14.7)$ & 29/229 (12.7) & & 16/73 (21.9) & 18/199 (9.1) & \\
\hline 1 & 223/819 (27.2) & $66 / 274(25.1)$ & $78 / 229(34.1)$ & & 10/73 (13.7) & $60 / 199(30.2)$ & \\
\hline $2-3$ & $331 / 819(40.4)$ & 119/274 (41.9) & $85 / 229(37.1)$ & & 29/73 (39.7) & $82 / 199(41.2)$ & \\
\hline$\geq 4$ & $151 / 819(18.4)$ & $50 / 274(18.4)$ & $37 / 229(16.2)$ & 0.11 & 18/73 (24.7) & 39/199 (19.6) & 0.004 \\
\hline \multicolumn{8}{|l|}{ Workplace n/N (\%) } \\
\hline Bar or nightclub & $580 / 820(70.7)$ & 179/274 (65.3) & $167 / 229(72.9)$ & & $52 / 73(71.2)$ & $149 / 200(74.5)$ & \\
\hline Home & $163 / 820(19.9)$ & $63 / 274(23.0)$ & $44 / 229(19.2)$ & & 14/73 (19.2) & $33 / 200(16.5)$ & \\
\hline Street & $54 / 820(6.6)$ & $23 / 274(8.4)$ & $10 / 229(4.4)$ & & $4 / 73(5.5)$ & 16/200 (8.0) & \\
\hline Hotel, guest house or other & 23/820 (2.8) & 9/274 (3.3) & $8 / 229(3.5)$ & 0.17 & $3 / 73(4.1)$ & $2 / 200(1.0)$ & 0.31 \\
\hline Age started sex work mean years (sd) | & $23.9(6.8)$ & $23.7(6.4)$ & $22.6(6.7)$ & 0.07 & $25.6(7.0)$ & $25.3(7.2)$ & 0.73 \\
\hline Duration of sex work median years (IQR) & $4(2-8)$ & $4(2-8)$ & $4(2-7)$ & 0.51 & $6(3-10)$ & $5(3-8)$ & 0.24 \\
\hline $\begin{array}{l}\text { Number of partners median in past week } \\
(\mathrm{IQR})^{*}\end{array}$ & $3(2-6)$ & $3(2-6)$ & $3(2-6)$ & 0.59 & $3(2-5)$ & $3(1-6)$ & 0.80 \\
\hline Condom use at last sex with client n/N (\%) & $661 / 819(80.7)$ & 210/273 (76.9) & 195/229 (85.2) & 0.02 & $58 / 73(79.5)$ & $161 / 200(80.5)$ & 0.85 \\
\hline \multicolumn{8}{|l|}{ Condom use (clients) n/N (\%) } \\
\hline Never & $17 / 820(2.1)$ & $11 / 274(4.0)$ & 3/229 (1.3) & & $1 / 73(1.4)$ & $1 / 200(0.5)$ & \\
\hline Inconsistent & 285/820 (34.8) & $102 / 274(37.2)$ & $78 / 229(34.1)$ & & 28/73 (38.4) & $62 / 200(31.0)$ & \\
\hline Always & $518 / 820(63.2)$ & $161 / 274(58.8)$ & $148 / 229(64.6)$ & 0.12 & $44 / 73(60.3)$ & $137 / 200(68.5)$ & 0.37 \\
\hline
\end{tabular}

$\mathrm{Chi}^{2}$ test unless indicated. ${ }^{*}$ Mann-Whitney $\mathrm{U}$ test; $\dagger$ chi-square test for trend; | Student's $t$ test^ Infection with HPV type $16,18,31,33,35,39,45,51,52,53,56$, $58,59,66$ and 68 defined as high-risk HPV infection 
assessment and from 789 women for HPV typing. More than half of FSW were infected with high-risk HPV (55.6\%; 439/789). Among these women, over half had at least two different high-risk HPV types (54.9\%; 241 / 439). HPV types 16 and/or 18 were detected in $22.8 \%$ of women (180/789), but more than twice as many were infected with high-risk HPV types other than 16 and 18 (48.5\%, 383/789). A quarter of women were infected with low-risk HPV type 6 and/or 67 (194/789).

Co-infection with both HIV and high-risk HPV occurred in $25.8 \%(200 / 776)$ of FSW (table 2). High-risk HPV was detected in $73.3 \%$ (200/273) of HIV-infected women versus $45.5 \%(229 / 503)$ of uninfected women, with an age-adjusted risk ratio (RR) of 1.7 (95\%CI RR = 1.5-1.9; $P<0.001)$. Co-infection with two or more highrisk HPV types was more frequent among HIV positive than negative women $(48.7 \%, 133 / 273$ versus $20.4 \%$, 103/506; $P<0.001)$. Fifteen percent of HIV-infected FSW had four or more high-risk HPV types.

\section{Predictors of high-risk HPV infection}

Among the whole study population, age was not associated with prevalence of high-risk HPV. However, in HIV-negative women, age effects were noted. Here, HPV prevalence decreased with increasing age, for example, $52.1 \%$ of HIV-negative women aged 17-24 years had high-risk HPV (88/169) while this figure was $38.6 \%$ in women older than 40 years $(22 / 57, P=0.02$; chi-square test for trend). Similarly, a linear decrease in the prevalence of HPV 16 and/or HPV 18 was noted in HIV-negative women, from a prevalence of $40.5 \%$ (32/ $169)$ in women below 25 years to $7.6 \%(6 / 57)$ in women above 40 years (odds of infection decreased by 0.71 with each increase in decade of age, $95 \% \mathrm{CI}=0.52-0.96 ; P=$ 0.03 , chi-square test for trend). Among women with HIV infection, the prevalence of HPV 16 and/or HPV 18 did not vary across age groups.

When adjusted for age, having a child and condom use, HIV status remained a predictor for high-risk HPV infection (adjusted odds ratio $[\mathrm{AOR}]=3.6 ; 95 \% \mathrm{CI}=$ 2.6-5.1; $P<0.001$; table 3 ). Having one or more children was also independently associated with high-risk HPV; these women had a 2.0 fold higher odds of high-risk HPV (95\%CI AOR $=1.3-3.3 ; P=0.003$ ) than women with no children. High levels of reported condom use were not protective against high-risk HPV infection, nor were other measures of sexual behaviour or sex work duration associated with HPV prevalence.

\section{Effect of HIV status on prevalence of specific high-risk HPV types}

Type-specific analysis showed that the most prevalent HPV types were similar in HIV-positive and -negative women. In decreasing order, the most prevalent high- risk HPV types among HIV-positive women were 52, $16,53,18,35$ and 66, while for HIV-negative women the order was HPV 16, 59, 35, 52, 66 and 53 (table 2).

Compared with HIV uninfected women, prevalence of all HPV types was higher in HIV-infected women, with the age-adjusted risk ratio a median 2.7 fold higher $(\mathrm{IQR} R \mathrm{R}=2.1-3.7$; range of $\mathrm{RRs}=1.4-5.5)$. HPV 16 and/or HPV 18 infection was found in 35.5\% (97/273) of HIV-positive women and in 15.7\% (79/503) of HIVnegative women $(P<0.001)$.

\section{HPV viral load}

HIV infection was significantly associated with an elevated HPV viral load for types 16, 31, 39, 45, 51, 52, 59 and 66. For 9 of the 15 high-risk HPV types measured, the median viral load for high-risk HPV was 5 or more times higher in HIV-positive than HIV-negative women. The total HPV viral load was 16.9 times higher in women with HIV infection compared to uninfected women (median 811 copies/cell versus 48 copies/cell; $P$ $<0.001)$.

\section{Cervical cytology}

High-risk HPV was strongly associated with abnormal cervical cytology, and was detected in $88.5 \%$ of women with HSIL (23/26) and $82.7 \%$ with LSIL (62/75). HPV type 16 and/or 18 was detected in $42.7 \%$ of women with LSIL (32/75) and 42.3\% with HSIL (11/26). However, high-risk HPV types other than 16 and 18 were more frequent, occurring in $74.7 \%$ of LSIL (56/75) and $84.6 \%$ of HSIL (22/26), even more so among HIV-infected women (12 of 13 women with HSIL). High-risk HPV type 52 (907 copies/cell) and low-risk type 67 were detected in the woman who had invasive carcinoma on cytology.

Half of women with a normal Pap smear had high-risk HPV (327/648), though high-risk HPV was more common among HIV-infected women with normal cytology (67.4\%; 130/193). Abnormal Pap smears were also markedly more common in HIV-infected women, of whom about 5\% had HSIL (13/269) and 20\% LSIL (54/269). The corresponding figures for HIV-negative women were $2.4 \%(12 / 503)$ and $4.2 \%(21 / 503)$, with one woman having squamous cell carcinoma. The $13 \mathrm{HIV}$-infected women with HSIL had a median of 3 high-risk HPV infections $(\mathrm{IQR}=2-3)$.

Of the $51 \mathrm{HIV}$-infected women whose total HPV viral load was $\geq 10^{4}$ copies/cell, 24 (47.1\%) had LSIL and 6 had HSIL lesions (11.8\%). Only $18 \mathrm{HIV}$-negative women had a total HPV viral load $=10^{4}$ copies/cell, of whom 4 had LSIL and 1 HSIL.

\section{Discussion}

In this study, about one-third of female sex workers were infected with HIV and more than half with high- 
Table 2 Association of HIV status with cervical cytology and prevalence of high-risk HPV types in female sex workers in Mombasa Kenya

\begin{tabular}{|c|c|c|c|c|c|c|}
\hline \multirow{2}{*}{$\begin{array}{l}\text { Variable } \\
\text { Prevalence of high-risk HPV }\end{array}$} & \multicolumn{2}{|c|}{ HIV-negative n/N (\%) } & \multicolumn{2}{|c|}{ HIV-positive n/N (\%) } & \multirow[t]{2}{*}{$P$} & \multirow[t]{2}{*}{$\begin{array}{c}\text { Risk ratio" } \\
(95 \% \mathrm{Cl})\end{array}$} \\
\hline & & & & & & \\
\hline Any high-risk HPV infection* & $N=503$ & $229(45.5)$ & $N=273$ & $200(73.3)$ & $<0.001$ & $1.7(1.5-1.9)$ \\
\hline Type 16 & & $56(11.1)$ & & $66(24.2)$ & $<0.001$ & $2.4(1.7-3.4)$ \\
\hline Type 18 & & $34(6.8)$ & & $51(18.7)$ & $<0.001$ & $2.9(1.9-4.6)$ \\
\hline Type 31 & & $31(6.2)$ & & $33(12.1)$ & 0.004 & $2.0(1.2-3.4)$ \\
\hline Type 33 & & $1(0.2)$ & & $3(1.1)$ & 0.095 & $4.3(0.41-45.8)$ \\
\hline Type 35 & & $39(7.8)$ & & $49(18.0)$ & $<0.001$ & $2.7(1.7-4.1)$ \\
\hline Type 39 & & $20(4.0)$ & & $36(13.2)$ & $<0.001$ & $4.2(2.3-7.5)$ \\
\hline Type 45 & & $18(3.6)$ & & $21(7.7)$ & 0.012 & $2.3(1.3-4.2)$ \\
\hline Type 51 & & $32(6.4)$ & & 39 (14.3) & $<0.001$ & $2.5(1.5-4.1)$ \\
\hline Type 52 & & $38(7.6)$ & & $70(25.6)$ & $<0.001$ & $3.7(2.5-5.6)$ \\
\hline Type 53 & & $35(7.0)$ & & $56(20.5)$ & $<0.001$ & $3.0(2.0-4.6)$ \\
\hline Type 56 & & $24(4.8)$ & & 39 (14.3) & $<0.001$ & $2.9(1.7-4.9)$ \\
\hline Type 58 & & $21(4.2)$ & & $15(5.5)$ & 0.40 & $1.4(0.7-2.7)$ \\
\hline Type 59 & & $43(8.6)$ & & $36(13.2)$ & 0.04 & $1.7(1.1-2.6)$ \\
\hline Type 66 & & $37(7.4)$ & & $40(14.7)$ & 0.001 & $2.1(1.3-3.3)$ \\
\hline Type 68 & & $2(0.4)$ & & $6(2.2)$ & 0.02 & $5.5(1.0-29.0)$ \\
\hline Mean high-risk HPV types (sd) & & $0.8(1.1)$ & & $1.8(1.8)$ & $<0.001$ & \\
\hline \multicolumn{7}{|l|}{ Low risk HPV } \\
\hline Type 6 & $N=503$ & $13(2.6)$ & $N=273$ & $10(3.7)$ & 0.40 & $1.4(0.63-3.3)$ \\
\hline Type 67 & & $87(17.3)$ & & $84(30.8)$ & $<0.001$ & $1.8(1.4-2.4)$ \\
\hline
\end{tabular}

Viral load of high-risk HPV types ( $\mathrm{n} \geq 1$ copy/cell; median (IQR))

\begin{tabular}{|c|c|c|c|c|}
\hline Type 16 & $38 ; 32.5(4-472)$ & & $52 ; 145(12-3278)$ & 0.016 \\
\hline Type 18 & $18 ; 12(4-58)$ & & $31 ; 31(6-718)$ & 0.23 \\
\hline Type 31 & $22 ; 15(3-572)$ & & $25 ; 208(58-13257)$ & 0.02 \\
\hline Type 33 & 1; 204 (NA) & & 3; 15453 (251-45 601) & 0.18 \\
\hline Type 35 & $34 ; 118(14-4882)$ & & 48; 302 (61-9969) & 0.11 \\
\hline Type 39 & $14 ; 13(1-89)$ & & $25 ; 106(3-2600)$ & 0.06 \\
\hline Type 45 & $14 ; 8(2-24)$ & & $21 ; 49(4-252)$ & 0.04 \\
\hline Type 51 & $30 ; 43(3-1738)$ & & $37 ; 826$ (34-43 983) & 0.02 \\
\hline Type 52 & $31 ; 12(3-71)$ & & $59 ; 76(5-938)$ & 0.05 \\
\hline Type 53 & $27 ; 5(2-14)$ & & $47 ; 31(1-288)$ & 0.14 \\
\hline Type 56 & 20; $112(5.5-829)$ & & $31 ; 219(20-1511)$ & 0.39 \\
\hline Type 58 & $12 ; 16(4.5-67)$ & & $13 ; 7(4-32)$ & 0.81 \\
\hline Type 59 & $21 ; 27(3-235)$ & & $20 ; 437(20-3552)$ & 0.04 \\
\hline Type 66 & 22; 4 (2-794) & & 35; 48 (7-1193) & 0.07 \\
\hline Type 68 & $0 ; 0$ & & $1 ; 1 ;(\mathrm{NA})$ & - \\
\hline otal high-risk HPV viral load & $48(6-756)$ & & $811(33-12$ 110) & $<0.001$ \\
\hline \multicolumn{5}{|l|}{ ervical cytology (Pap smear) } \\
\hline Normal & $461(91.7)$ & $N=269$ & $196(72.9)$ & \\
\hline ASC-US/ASC-H & $8(1.6)$ & & $6(2.2)$ & \\
\hline LSIL & $21(4.2)$ & & $54(20.1)$ & \\
\hline HSIL & $12(2.4)$ & & $13(4.8)$ & \\
\hline Invasive carcinoma & $1(0.2)$ & & $0(0)$ & $<0.001$ \\
\hline
\end{tabular}

Anfection with HPV type $16,18,31,33,35,39,45,51,52,53,56,58,59,66$ and 68 defined as high-risk HPV infection. ${ }^{*}$ Any detectable HPV viral load $>0$ copies/ cell considered diagnostic. \#Age-adjusted risk ratio. LSIL low-grade intraepithelial lesion; HSIL high-grade squamous intra-epithelial lesion; ASC-US atypical squamous cells of undetermined significance; ASC-H atypical squamous cells: cannot exclude high-grade squamous intra-epithelial lesion. Median copies/cell are rounded to closest whole number. Vari. Cat. Variable category 
Table 3 Association of HIV and other covariates with high-risk HPV infection: multivariable logistic regression analysis

\begin{tabular}{|c|c|c|c|}
\hline Variable & $\begin{array}{c}\text { Unadjusted odds ratio } \\
(95 \% \mathrm{Cl})\end{array}$ & $\begin{array}{c}\text { Adjusted odds ratio } \\
(95 \% \mathrm{Cl})\end{array}$ & $P$ \\
\hline \multicolumn{4}{|l|}{ Age } \\
\hline $17-24$ & $1.3(0.80-2.0)$ & $1.9(1.1-3.2)$ & 0.014 \\
\hline $25-29$ & $1.3(0.83-2.1)$ & $1.5(0.92-2.5)$ & 0.10 \\
\hline 30-39 & $1.0(0.66-1.7)$ & $1.1(0.69-1.7)$ & 0.81 \\
\hline$\geq 40$ & 1.0 & 1.0 & \\
\hline \multicolumn{4}{|c|}{ Have one or more children } \\
\hline No & 1.0 & 1.0 & \\
\hline Yes & $1.5(1.0-2.3)$ & $2.0(1.3-3.3)$ & 0.003 \\
\hline \multicolumn{4}{|c|}{ Condom use with client at last sex } \\
\hline No & 1.0 & 1.0 & \\
\hline Yes & $1.5(1.0-2.1)$ & $1.4(0.96-2.1)$ & 0.08 \\
\hline \multicolumn{4}{|c|}{ HIV infection } \\
\hline No & 1.0 & 1.0 & \\
\hline Yes & $3.3(2.4-4.5)$ & $3.6(2.6-5.1)$ & $<0.001$ \\
\hline
\end{tabular}

risk HPV. In multivariable analysis, high-risk HPV was more than three times as common among HIV-positive than negative women. Prevalence of high-risk HPV in the study population is notably higher than in a metaanalysis of HIV-infected women including 20 studies, mostly from North America [28]. Though it is difficult to make direct comparisons between studies as HPV detection methods differ, the prevalence in this study is similar to a recent study among HIV-infected female hospital patients in Zambia [29]. Also of note, among HIV-infected women who had normal cervical cytology, two thirds had high-risk HPV infection in this study, twice as many as the meta-analysis of HIV-infected women [28]. Prevalence of high-risk HPV in HIV-negative FSW in our study is similar to previous reports among sex workers in other settings, for example, 39\% in Spain [6], 43\% in Mexico [30] and 48\% in Japan [8], though a study in Calcutta, India reported higher levels (63\%) [7].

Simultaneous infection with multiple HPV types was more frequent in HIV-positive women. This finding is consistent with previous reports [28], and according to Chaturvedi et al [31], is attributable to the common mode of transmission of HPV and HIV; the inability to clear HPV infections; as well as reactivation of latent HPV infections, the latter two occurring as a result of immune suppression [9,32-34]. Similar factors may underlie the concerning high levels of HPV 16 and 18 noted in older HIV-positive women in this study [35]. Though here, a particular ability of HPV 16 to evade immune surveillance in HIV-positive women may account for the high levels noted in all age groups [34].

Persistent HPV infection is the main cause of cervical cancer, and since this is more common in HIV-infected women, it makes the presence of cervical lesions in a quarter of HIV-positive women in this study even more concerning [36]. Many previous studies, including one in Mombasa [37], have noted a higher prevalence of HSIL among HIV-positive than HIV-negative women [38-40].

Broadly, the distribution of high-risk HPV types were similar in HIV-infected and uninfected women, albeit that the most common HPV types occurred in slightly differing order of prevalence. However, the most common HPV types in our study differ from those in other settings $[28,40]$. These regional differences in HPV types might, at least partly, be attributed to HIV and its differential effects on the natural history of specific types. However, not all findings support this assertion [41].

An association between parity and high-risk HPV has been noted previously, though might be accounted for by confounding due to sexual behaviour, such as unprotected sex or age at coital debut $[6,35,42]$. A large multicentre case-control study suggests, however, that full-term pregnancy is a cofactor that increases the risk of progression from HPV infection to cancer [35]. This, the authors speculate, might be due to hormonal changes in the second and third trimester of pregnancy or to increased cervical ectopy with multiparity. Possibly, the reduction in cervical cancer noted worldwide might be partly explained by the general global decline in parity.

Age, as previously shown $[6,30,43,44]$, is an important predictor of HPV infection, with younger women being more frequently infected. Again, the absence of age effects among HIV-infected women in our study may be explained by a decreased ability to clear HPV infection, reactivation of HPV or re-infection with HPV types previously cleared, all of which likely occur more commonly in HIV-infected women. 
Results presented here are consistent with a meta-analysis by De Vuyst et al. describing higher median viral loads of high-risk HPV in HIV-positive women, regardless of HPV type [45]. HPV viral load possibly correlates with the immune deficiency in these patients [10] and with likelihood of persistent HPV infection [46]. The highest viral burdens were found with HPV 33 in HIVpositive women and HPV 56 in HIV-negative women. HPV 16 had a relatively low viral load, though even at low viral levels has high oncogenic potential $[47,48]$.

Even though current HPV vaccines offer some crossprotection against several HPV types [49], type-specific analysis of HPV data remains important for informing future HPV vaccine development and distribution. In women attending a family planning clinic in Nairobi, Kenya, less than $10 \%$ had HPV 16 and/or 18, and these types were present in about $40 \%$ of HSIL lesions [50]. In our study, HPV 16 and/or HPV 18 were present in about $20 \%$ of study participants, while still in about $40 \%$ of women with LSIL or HSIL. However, that most cervical lesions were negative for HPV 16 and/or 18, suggests that other high-risk HPV types might play a more important role in this context of female sex work. These types appear of particular importance in HSIL lesions in HIV-infected women [28]. It is also possible that the specific oncogenic HPV types that contribute to the development of cervical cancer in HIV-positive women may differ from those in HIV-negative women [51].

It is difficult to ascertain to what degree the sample obtained through snowballing methods is representative of the FSW population in Mombasa. Though snowball sampling is appropriate for locating difficult-to-reach populations, as it is a non-random sampling method, selection bias may occur. The investigators elected to have a large sample size, in an attempt to mitigate such effects. As a further limitation, information was missing on both HIV and high-risk HPV types, which could introduce bias. Such bias, however, is likely minimal as the missing information can be assumed to be non-differential in nature [52].

Patterns of HPV prevalence will likely alter the impact of prophylactic HPV vaccination [53]. The extent of this would be better understood if more information was available on the natural history of dysplasia associated with HPV types other than 16 and 18. The study population described here is highly suited to prospective assessment of this and related topics, given the considerable burden on HPV disease in this population. Moreover, previous cohorts in this study population have been feasible, with more than $90 \%$ cohort retention rates $[54,55]$.

\section{Conclusion}

Given the common occurrence of high-grade cervical lesions, especially in HIV-infected women, regular HPV screening and follow-up is essential for prevention of cervical cancer. Even though much is known about these diseases and their optimal control, current measures to prevent HIV and HPV in this population are clearly inadequate. The lack of control of these infections means that sex workers likely play a disproportionate role in transmission dynamics of both infections in the general population. Additional prevention measures, especially higher population-level coverage with HPV vaccine, are required.

\section{Acknowledgements}

The authors wish to gratefully acknowledge the women who participated in this study and all the ICRH staff who contributed to this work. This work was supported by the International Partnership for Microbicides (IPM) and Family Health International (FHI). The authors of this publication also received funding from the EDCTP through a project entitled "Preparing for Phase III vaginal microbicide trials in Rwanda and Kenya: Preparedness studies, capacity building, and strengthening of medical referral systems." However, EDCTP cannot accept any responsibility for information or views expressed herein. DVB is supported by the Fund for Scientific Research Flanders (FWOVlaanderen) and JPB is supported by the Belgian Cancer Foundation (Belgische Stichting tegen Kanker). WD is supported by the Institute for the Promotion of Innovation by Science and Technology in Flanders (IWT).

\section{Author details}

${ }^{1}$ International Centre for Reproductive Health (ICRH), Mombasa, Kenya. ${ }^{2}$ International Centre for Reproductive Health (ICRH), Ghent University, Belgium. ${ }^{3}$ Reproductive Health and HIV Research Unit (RHRU), University of Witwatersrand, South Africa. ${ }^{4}$ International Partnership for Microbicides (IPM), Paarl, South Africa. ${ }^{5}$ Coast Provincial General Hospital (CPGH), Mombasa, Kenya. ${ }^{6}$ Applied Molecular Biology Research (AMBIOR), University of Antwerp, Belgium. 'Laboratory for clinical pathology (Labo Lokeren - Campus Riatol), Antwerp, Belgium. ${ }^{8}$ South African Centre for Epidemiological Modelling and Analysis, Stellenbosch University, South Africa.

\section{Authors' contributions}

SL participated in the design of the study, supervised the study and contributed to interpretation of findings and drafting of the final manuscript DVB and MFC assisted in drafting the manuscript. MFC and WD performed the data analysis. AN critically reviewed the manuscript and assisted in interpretation of the study findings. KM participated in the study coordination, collection of data and helped draft the manuscript. CED analysed the samples and assisted in interpretation of the results. PC, JPB and MT made a substantial contribution to the study design and interpretation of findings. All authors read and approved the final manuscript.

\section{Competing interests}

The authors declare that they have no competing interests.

Received: 23 September 2009

Accepted: 26 January 2010 Published: 26 January 2010

\section{References}

1. Parkin DM, Bray F: Chapter 2: The burden of HPV-related cancers. Vaccine 2006, 24(Suppl 3):S11-25

2. International Agency for Research on Cancer: Human papillomaviruses. IARC Monographs on the Evaluation of Carcinogenic Risks to Humans 2006, 90.

3. de Villiers EM, Fauquet C, Broker TR, Bernard HU, zur Hausen H: Classification of papillomaviruses. Virology 2004, 324(1):17-27.

4. Bouvard V, Baan R, Straif K, Grosse $Y$, Secretan B, El Ghissassi F, BenbrahimTallaa L, Guha N, Freeman C, Galichet L, et al: A review of human carcinogens-Part B: biological agents. Lancet Oncol 2009, 10(4):321-322.

5. McClelland RS, Ndinya-Achola JO, Baeten JM: Re: distinguishing the temporal association between women's intravaginal practices and risk 
of human immunodeficiency virus infection: a prospective study of South African women. Am J Epidemiol 2007, 165(4):474-475, author reply 475-476.

6. del Amo J, Gonzalez C, Losana J, Clavo P, Munoz L, Ballesteros J, GarciaSaiz A, Belza MJ, Ortiz M, Menendez B, et al: Influence of age and geographical origin in the prevalence of high risk human papillomavirus in migrant female sex workers in Spain. Sex Transm Infect 2005, 81(1):79-84

7. Chatterjee R, Mukhopadhyay D, Murmu N, Jana S: Prevalence of human papillomavirus infection among prostitutes in Calcutta. J Environ Pathol Toxicol Oncol 2001, 20(2):113-117.

8. Ishi K, Suzuki F, Saito A, Kubota T: Prevalence of human papillomavirus infection and its correlation with cervical lesions in commercial-sex workers in Japan. J Obstet Gynaecol Res 2000, 26(4):253-257.

9. Strickler HD, Burk RD, Fazzari M, Anastos K, Minkoff H, Massad LS, Hall C, Bacon M, Levine AM, Watts DH, et al: Natural history and possible reactivation of human papillomavirus in human immunodeficiency viruspositive women. J Natl Cancer Inst 2005, 97(8):577-586.

10. De Vuyst H, Lillo F, Broutet N, Smith JS: HIV, human papillomavirus, and cervical neoplasia and cancer in the era of highly active antiretroviral therapy. Eur J Cancer Prev 2008, 17(6):545-554.

11. Mandelblatt JS, Kanetsky P, Eggert L, Gold K: Is HIV infection a cofactor for cervical squamous cell neoplasia? Cancer Epidemiol Biomarkers Prev 1999, 8(1):97-106.

12. Wallin KL, Wiklund F, Angstrom T, Bergman F, Stendahl U, Wadell G Hallmans G, Dillner J: Type-specific persistence of human papillomavirus DNA before the development of invasive cervical cancer. N Engl I Med 1999, 341(22):1633-1638.

13. Palefsky JM: Cervical human papillomavirus infection and cervical intraepithelial neoplasia in women positive for human immunodeficiency virus in the era of highly active antiretroviral therapy. Curr Opin Oncol 2003, 15(5):382-388.

14. Dunkle KL, Jewkes RK, Brown HC, Gray GE, McIntryre JA, Harlow SD: Transactional sex among women in Soweto, South Africa: prevalence, risk factors and association with HIV infection. Soc Sci Med 2004, 59(8):1581-1592.

15. Yeoh GP, Tse MP, Chan KW, Lord L: Human papillomavirus DNA and liquid-based cervical cytology cotesting in screening and follow-up patient groups. Acta Cytol 2006, 50(6):627-631

16. Kirungi WL, Musinguzi J, Madraa E, Mulumba N, Callejja T, Ghys P, Bessinger R: Trends in antenatal HIV prevalence in urban Uganda associated with uptake of preventive sexual behaviour. Sex Transm Infect 2006, 82(Suppl 1):i36-41.

17. Chin-Hong PV, Husnik M, Cranston RD, Colfax G, Buchbinder S, Da Costa M, Darragh $T$, Jones D, Judson F, Koblin B, et al: Anal human papillomavirus infection is associated with HIV acquisition in men who have sex with men. AIDS 2009, 23(9):1135-1142.

18. Auvert B, Lissouba P, Cutler E, Zarca K, Puren A, Taljaard D: Is genital human papillomavirus infection associated with HIV incidence? 5th IAS conference on HIV pathogenesis, treatment and prevention: 2009; Cape Town, South Africa 2009.

19. Smith JC, Moses S, Hudgens M, Parker CB, Agot K, Maclean I, NdinyaAchola JO, Snijders PJF, Meijer CJLM, Bailey RC: Risk of HIV acquisition among men with and without human papillomavirus infection in Kisumu, Kenya. 5th IAS conference on HIV pathogenesis, treatment and prevention 2009; Cape Town, South Africa 2009.

20. WHO: Human papillomavirus and HPV vaccines: technical information for policy-makers and health professionals. 2007.

21. WHO: Global Immunization Data. 2009. [http://www.who.int/ immunization/newsroom/GID_english.pdf].

22. Hawken MP, Melis RD, Ngombo DT, Mandaliya K, Ng'ang'a LW, Price J, Dallabetta G, Temmerman M: Part time female sex workers in a suburban community in Kenya: a vulnerable hidden population. Sex Transm Infect 2002, 78(4):271-273.

23. Luchters S, Chersich MF, Rinyiru A, Barasa MS, King'ola N, Mandaliya K Bosire W, Wambugu S, Mwarogo P, Temmerman M: Impact of five years of peer-mediated interventions on sexual behavior and sexually transmitted infections among female sex workers in Mombasa, Kenya. BMC Public Health 2008, 8:143.

24. Ulin PR, Robinson E, Tolley EE: Qualitative methods in public health: a field guide for applied research. Published by Jossey-Bass 2005 .
25. Davey DD: Cervical cytology classification and the Bethesda System. Cancer J 2003, 9(5):327-334

26. Depuydt CE, Benoy IH, Bailleul EJ, Vandepitte J, Vereecken AJ, Bogers JJ: Improved endocervical sampling and HPV viral load detection by Cervex-Brush Combi. Cytopathology 2006, 17(6):374-381.

27. Armitage B, Berry G, Matthews JNS: Statistical methods in medical research. Blackwell publishing 2002.

28. Clifford GM, Goncalves MA, Franceschi S: Human papillomavirus types among women infected with HIV: a meta-analysis. AIDS 2006, 20(18):2337-2344.

29. Ng'andwe C, Lowe JJ, Richards PJ, Hause L, Wood C, Angeletti PC: The distribution of sexually-transmitted Human Papillomaviruses in HIV positive and negative patients in Zambia, Africa. BMC Infect Dis 2007, 7:77.

30. Juarez-Figueroa LA, Wheeler CM, Uribe-Salas FJ, Conde-Glez CJ, ZampilpaMejia LG, Garcia-Cisneros S, Hernandez-Avila M: Human papillomavirus: a highly prevalent sexually transmitted disease agent among female sex workers from Mexico City. Sex Transm Dis 2001, 28(3):125-130.

31. Chaturvedi AK, Myers L, Hammons AF, Clark RA, Dunlap K, Kissinger PJ, Hagensee ME: Prevalence and clustering patterns of human papillomavirus genotypes in multiple infections. Cancer Epidemiol Biomarkers Prev 2005, 14(10):2439-2445.

32. Palefsky JM, Minkoff $H$, Kalish LA, Levine A, Sacks HS, Garcia P, Young M, Melnick S, Miotti P, Burk R: Cervicovaginal human papillomavirus infection in human immunodeficiency virus-1 (HIV)-positive and high-risk HIVnegative women. J Natl Cancer Inst 1999, 91(3):226-236.

33. Levi JE, Fernandes S, Tateno AF, Motta E, Lima LP, Eluf-Neto J, Pannuti CS: Presence of multiple human papillomavirus types in cervical samples from HIV-infected women. Gynecol Oncol 2004, 92(1):225-231.

34. Strickler HD, Palefsky JM, Shah KV, Anastos K, Klein RS, Minkoff H, Duerr A, Massad LS, Celentano DD, Hall C, et al: Human papillomavirus type 16 and immune status in human immunodeficiency virus-seropositive women. J Natl Cancer Inst 2003, 95(14):1062-1071.

35. Munoz N, Franceschi S, Bosetti C, Moreno V, Herrero R, Smith JS, Shah KV, Meijer CJ, Bosch FX: Role of parity and human papillomavirus in cervical cancer: the IARC multicentric case-control study. Lancet 2002, 359(9312):1093-1101.

36. Munoz N, Bosch FX, de Sanjose S, Tafur L, Izarzugaza I, Gili M, Viladiu P, Navarro C, Martos C, Ascunce N, et al: The causal link between human papillomavirus and invasive cervical cancer: a population-based casecontrol study in Colombia and Spain. Int J Cancer 1992, 52(5):743-749.

37. Chersich MF, Luchters SM, Yard E, Othigo JM, Kley N, Temmerman M: Morbidity in the first year postpartum among HIV-infected women in Kenya. Int J Gynaecol Obstet 2008, 100(1):45-51.

38. Temmerman M, Tyndall MW, Kidula N, Claeys P, Muchiri L, Quint W: Risk factors for human papillomavirus and cervical precancerous lesions, and the role of concurrent HIV-1 infection. Int J Gynaecol Obstet 1999, 65(2):171-181

39. Dal Maso L, Franceschi S, Polesel J, Braga C, Piselli P, Crocetti E, Falcini F Guzzinati S, Zanetti R, Vercelli M, et al: Risk of cancer in persons with AIDS in Italy, 1985-1998. Br J Cancer 2003, 89(1):94-100.

40. Clifford GM, Gallus S, Herrero R, Munoz N, Snijders PJ, Vaccarella S, Anh PT, Ferreccio C, Hieu NT, Matos E, et al: Worldwide distribution of human papillomavirus types in cytologically normal women in the International Agency for Research on Cancer HPV prevalence surveys: a pooled analysis. Lancet 2005, 366(9490):991-998.

41. Odida M, de Sanjose S, Quint W, Bosch XF, Klaustermeier J, Weiderpass E: Human Papillomavirus type distribution in invasive cervical cancer in Uganda. BMC Infect Dis 2008, 8:85.

42. Dames DN, Ragin C, Griffith-Bowe A, Gomez P, Butler R: The prevalence of cervical cytology abnormalities and human papillomavirus in women infected with the human immunodeficiency virus. Infect Agent Cancer 2009, 4(Suppl 1):S8.

43. Burk RD, Kelly P, Feldman J, Bromberg J, Vermund SH, DeHovitz JA, Landesman SH: Declining prevalence of cervicovaginal human papillomavirus infection with age is independent of other risk factors. Sex Transm Dis 1996, 23(4):333-341.

44. Woodman CB, Collins S, Winter H, Bailey A, Ellis J, Prior P, Yates M, Rollason TP, Young LS: Natural history of cervical human papillomavirus infection in young women: a longitudinal cohort study. Lancet 2001, 357(9271):1831-1836. 
45. De Vuyst H, Clifford GM, Nascimento MC, Madeleine MM, Franceschi S: Prevalence and type distribution of human papillomavirus in carcinoma and intraepithelial neoplasia of the vulva, vagina and anus: a metaanalysis. Int J Cancer 2009, 124(7):1626-1636.

46. Fontaine J, Hankins C, Money D, Rachlis A, Pourreaux K, Ferenczy A, Coutlee F: Human papillomavirus type 16 (HPV-16) viral load and persistence of HPV-16 infection in women infected or at risk for HIV. J Clin Virol 2008, 43(3):307-312.

47. Clifford GM, Smith JS, Plummer M, Munoz N, Franceschi S: Human papillomavirus types in invasive cervical cancer worldwide: a metaanalysis. Br J Cancer 2003, 88(1):63-73.

48. Munoz N, Bosch FX, de Sanjose S, Herrero R, Castellsague X, Shah KV, Snijders PJ, Meijer CJ: Epidemiologic classification of human papillomavirus types associated with cervical cancer. N Engl J Med 2003, 348(6):518-527.

49. De Carvalho NS: Cervical cancer vaccination: the real meaning of crossprotection and its impact on the prevention. Vaccine 2008, 26(50):6293-6294.

50. De Vuyst H, Steyaert S, Van Renterghem L, Claeys P, Muchiri L, Sitati S, Vansteelandt S, Quint W, Kleter B, Van Marck E, et al: Distribution of human papillomavirus in a family planning population in nairobi, kenya. Sex Transm Dis 2003, 30(2):137-142.

51. Palefsky JM, Gillison ML, Strickler HD: Chapter 16: HPV vaccines in immunocompromised women and men. Vaccine 2006, 24(Suppl 3): S140-146.

52. Schulz KF, Grimes DA: Sample size slippages in randomised trials: exclusions and the lost and wayward. Lancet 2002, 359(9308):781-785.

53. Smith JS, Lindsay L, Hoots B, Keys J, Franceschi S, Winer R, Clifford GM: Human papillomavirus type distribution in invasive cervical cancer and high-grade cervical lesions: a meta-analysis update. Int J Cancer 2007, 121(3):621-632.

54. Thomsen SC, Ombidi W, Toroitich-Ruto C, Wong EL, Tucker HO, Homan R, Kingola N, Luchters S: A prospective study assessing the effects of introducing the female condom in a sex worker population in Mombasa, Kenya. Sex Transm Infect 2006, 82(5):397-402.

55. Bosire W, Luchters S, Nel A, Malava E, Malonza I, Temmerman M: A prospective microbicides preparedness study for estimation of HIV-1 incidence among female sex workers in Mombasa, Kenya. Microbicides 2008: 2008; New Delhi, India 2008.

\section{Pre-publication history}

The pre-publication history for this paper can be accessed here: http://www. biomedcentral.com/1471-2334/10/18/prepub

doi:10.1186/1471-2334-10-18

Cite this article as: Luchters et al:: Association of HIV infection with distribution and viral load of HPV types in Kenya: a survey with 820 female sex workers. BMC Infectious Diseases 2010 10:18.

\section{Submit your next manuscript to BioMed Central and take full advantage of:}

- Convenient online submission

- Thorough peer review

- No space constraints or color figure charges

- Immediate publication on acceptance

- Inclusion in PubMed, CAS, Scopus and Google Scholar

- Research which is freely available for redistribution

Submit your manuscript at www.biomedcentral.com/submit
Biomed Central 